TITLE:

\title{
A CREEPING CTENOPHORE FOUND ON THE SEA CUCUMBER, HOLOTHURIA LEUCOSPILOTA (BRANDT)
}

$\operatorname{AUTHOR(S):~}$

Tokioka, Takasi

CITATION:

Tokioka, Takasi. A CREEPING CTENOPHORE FOUND ON THE SEA CUCUMBER, HOLOTHURIA LEUCOSPILOTA (BRANDT). PUBLICATIONS OF THE SETO MARINE BIOLOGICAL LABORATORY 1969, 17(4):279-283

ISSUE DATE:

1969-12-27

URL:

http://hdl.handle.net/2433/175600

RIGHT: 


\title{
A CREEPING CTENOPHORE FOUND ON THE SEA CUCUMBER, HOLOTHURIA LEUCOSPILOTA (BRANDT) ${ }^{1)}$
}

\author{
TAKASI TOKIOKA
}

Seto Marine Biological Laboratory

With 1 Text-figure

On June 1 this year, Mr. Torao Yамамото presented me for identification a specimen of creeping ctenophore which was found by one of the students of Wakayama University, who were engaged in the field observations under the direction of Mr. Yамамото, in the boulder area of the intertidal zone of Hatakezima Island on the body surface of the tropical black sea cucumber, Holothuria leucospilota (BRANDT). The specimen was evidently a species of Coeloplana and $4.5 \mathrm{~mm}$ long in a considerably extended state (Fig. $1 \mathrm{~A}$ and B). It would be somewhat longer in a fully extended state which was, however, never shown during my observation. The periphery of the body is apt to show a shallow notch at each tentacular side. The tentaclesheath opens on the dorsal side slightly apart from the margin. The central area including the tentacular apparatuses is considerably swollen on the dorsal surface and furnished with dorsal tentacles which consist of about six larger and up to eight smaller ones. The exact number of dorsal tentacles and their distribution could not be seen, because they were alternately extended or contracted on the body which was also incessantly repeating irregular contraction and extension. On the other hand, the site of the aboral sense-organ could not be confirmed exactly, though a pit(Fig. 1 A, ap) was formed sometimes at about one-third of the body length on the median line. The pit was contracted or extended most actively. It became quite obscure by contraction or assumed a short siphon (Fig. 1 B, ap) when it extended fully. As the situation of this pit was corresponding to the centre of the complicatedly folded adult pharynx which was seen clearly on the underside of the body, I guessed that the pit must be the apical pit holding the aboral sense-organ on the bottom. To confirm this later, the specimen was preserved in formalin. Then, the dorsal tentacles are arranged quite asymmetrically in the tentacular axis. As Coeloplana regenerates actively as suggested by Аввотт (1902, p. 105) and $\operatorname{Komar}(1922$, p. 8) and confirmed by experiment by TANAKA (1931), this specimen might be in a certain stage of regeneration. Or, this was treated somewhat ungently when it was detached from the

1) Contributions from the Seto Marine Biological Laboratory, No. 514.

Publ. Seto Mar. Biol. Lab., XVII (4), 279-283, 1969. (Article 14) 


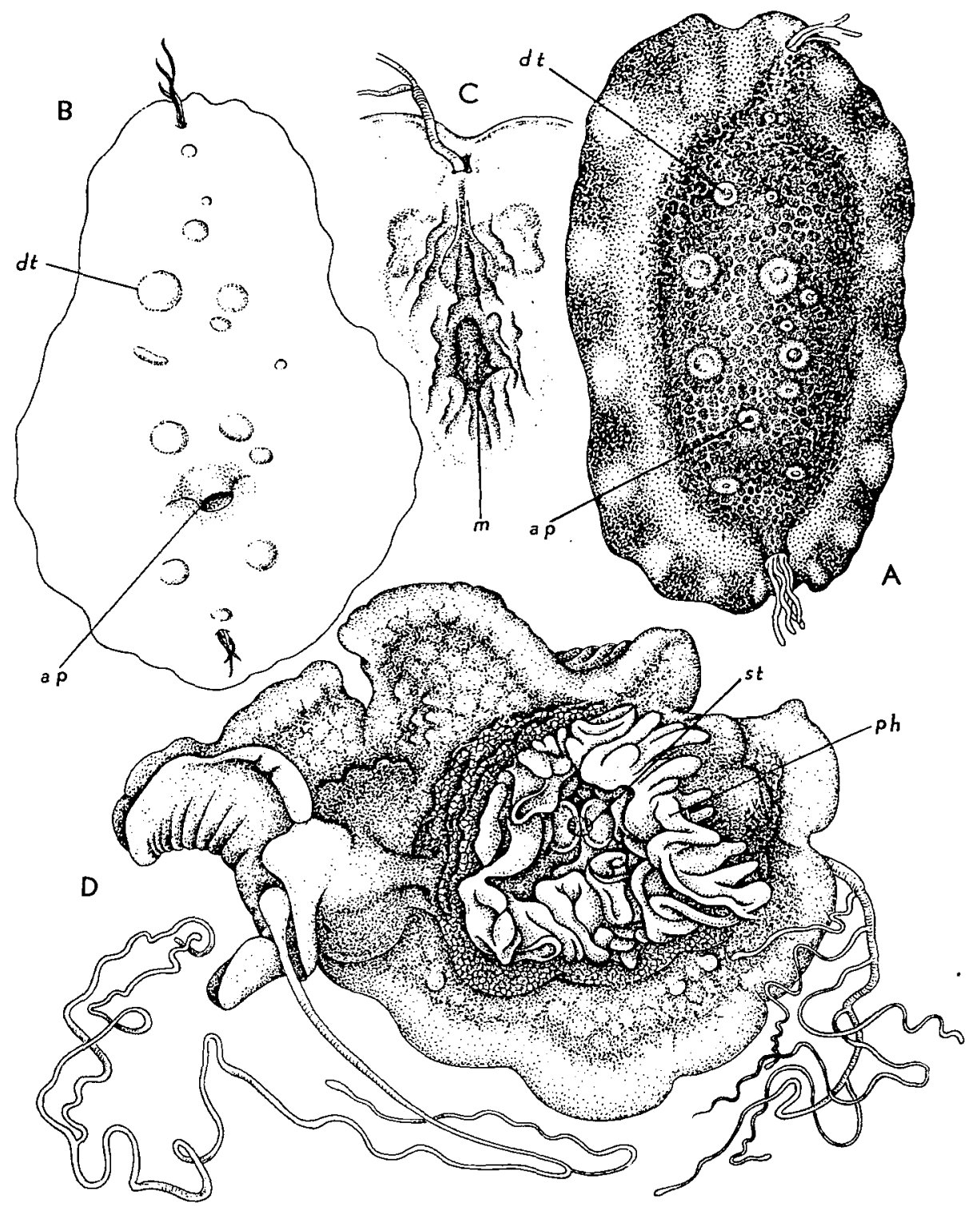

Fig. 1. ?Coeloplana willeyi Аввотт. A: Dorsal side of live specimen, 5 larger and 5 smaller dorsal tentacles are extended out in the larger extensible tentacular half of the body (above the level of ap). B: Another phase of the distribution of dorsal tentacles, 5 larger and 6 smaller ones are seen in the larger extensile tentacular half of the body (above the level of ap). C: Ventral side surrounding the sheath of the right tentacle shown in D. D: Dorsal side of preserved specimen. ap.. apical pit, dt.. dorsal tentacle, m.. mouth, ph..pharynx, st..statocyst. 
sea cucumber so that the body half shocked more heavily would not be relaxed. To obtain perfect specimens, KomaI mentions (1922, p. 7) as "To detach them from the substratum to which they adhere, it is necessary to use a pippet, otherwise the specimens will always suffer damage."

The body is translucent and is covered on the dorsal surface with dense dark red to purplish brown pigment spots. The pigment distribution is shown roughly in Fig. $1 \mathrm{~A}$. The periphery is bordered with dark and whitish patches and the submarginal zone is sparsely pigmented. The central area is covered throughout with heavily pigmented small spots, except for the base of each dorsal tubercle, which is pigmented white. These white rings, however, become completely invisible when dorsal tentacles are contracted. The underside of the body is entirely unpigmented. The tentacles are branched and are coloured white. The basal portion of tentacles is yellowish.

According to Mr. Yамамото, the body colour had been somewhat faded when the specimen was forwarded to me, then it faded further a little during my observation. When it was fixed in formalin, the solution became pinkish in a short time and the animal rapidly faded away into pinkish, and 24 hours after fixation the body was quite whitish except the dorsal side of tentacle-sheathes, which was still pinkish. Then on October 14, 136 days after the fixation, the body was wholly light brownish, although the tentacle-root and the compartments of tentacle-sheath were still yellowish.

When the preserved specimen was observed to confirm the exact situation of the aboral sense-organ, it was a great surprise that a rosette was formed with its centre at one third of the tentacular axis. Detailed observations made it clear immediately that the rosette was nothing but the inner section of pharynx (Fig. $1 \mathrm{D}, \mathrm{ph}$ ) folded complicatedly. The thin dorsal body wall covering the pharynx is evidently shrunk so that the pharynx is exposed around the aboral sense-organ. The statocyst (Fig. 1 $\mathrm{D}$, st) is seen between a pair of semicircular lappets arraged in the tentacular axis, but it is uncertain whether or not this is a normal morphology. Tentacles are clearly issued from the underside (Fig. 1 G). Thus it is clear that this morphology seen in the preserved specimen does not represent the feature of the live specimen. Tentacles are very long. One is provided with five branches, while the other with two branches; probably some branches are lost in this specimen. Anyhow, the distal-most branch is so prominent that it is very difficult to distinguish the tentacle-stem and the branch from each other.

Considerations: Apart from the association with Holothuria, the present specimen seems to be related most closely with Coeloplana willeyi Аввотт, 1902 of the five species occurring in the vicinity of Seto. The dorsal tentacles are not so numerous even in the extensible larger tentacular half nor prominent as in $C$. willeyi, but this can not be considered to be very significant; this will rather depend on the state of the animal. The general colouration of the present specimen can be included within the range of colour variation of $C$. willeyi; the white pigmentation around the 
base of dorsal tentacles is common to $C$. willeyi and the present specimen. However, the peripheral colour pattern seems to differ somewhat between the two. In $C$. zeilleyi, the margin is furnished with much more but much smaller white pigment spots, but in the present specimen with rather larger but much fewer white pigment patches. The shape of the apical pit in the present specimen differs somewhat, too, from that of $C$. willeyi given by Аввотт $(1907$, p. 68). The strange form of the apical pit in the present specimen, however, might be attributable to some damage of the body wall around the aboral sense-organ, and this damage might cause the shrinkage of the body wall over the pharynx in the preserved specimen. Summing up these features, I tend to consider, at present, the specimen as an intraspecific variant of C. willeyi, as actually I found two typical grayish purple individuals of this species under the stone in the same area of Hatakezima Island later on July 28.

Komal (1922, p. 9) mentions that Coeloplana will take nearly the same food as pelagic ctenophores or Tjalfiella. However, this does not seem to apply to the species associated obligatorily with respective host animals (octocorals and echinoderms). The host animals very probably not only afford the substratum to Coeloplana but also special food material to them. Their epithelium itself or its mucid secretion must constitute the staple of food of Coeloplana associated with them, although nothing identifiable will remain in the pellets ejected from the mouth of Coeloplana. C. willeyi is generally living on stones and algae and its colouration is exceptionally variable among the species of Coeloplana. It is not impossible that this reflects the omnivorous habit of this animal. The dark colouration of the present specimen seems to be attributable to the pigment of Holothuria taken up. So rapid fading and so easy solubility of the pigment in the present specimen remind us of those of Holothuria leucospilota. Holothuria does not seem to be exceptional as the substratum, because so far four other species of Coeloplana are known as associated with echinoderms: C. astericola Mortensen, 1927 with a starfish (Echinaster), C. echinicola TANAKA, 1932 (with Toxopneustes), C. bannwarthi KRumbaCH, 1933 (with Diadema), and C. weilli DAwYdoff, 1938 (with Heterocentrotus) with sea urchins. Especially, C. willeyi is recorded from the surface of the sea urchin, Echinothrix diadema (LinNaEus), in Hawaiian waters (MATTHEws and TownsLey, 1964). If more specimens are found repeatedly on this sea cucumber, and they are similarly provided with some of the above-mentioned features of the present specimen, which differ somewhat from those of $C$. willeyi, then the present specimen must be treated as the first specimen of a new species distinct from $C$. willeyi.

If the present specimen is truly $C$. willeyi, it was probably found moving contingently on the sea cucumber and possibly feeding on it, as the case of the pycnogonid Ammothea (=Lecythorhynchus) hilgendorfi (Böнm) observed by OHsнima on Holothuria leucospilota. This sea cucumber is very famous for its saponin-like toxin holothurin contained in the skin as noted repeatedly, but this poison seems ineffectual to some invertebrates as it is indicated by the snail Balcis kuronamako $\mathrm{HABE}_{\mathrm{ABE}} 1952$ which is 
epiparasitic on this sea cucumber.

Before closing this note I want to express my hearty thanks to Mr. T. Үамамото for the specimen and to Dr. H. UTiNomi for the information about the pycnogonid found on Holothuria leucospilota.

\section{REFERENGES}

Аввотт, J.F. (1902): Preliminary notes on Coeloplana. Annot. Zool. Japon., Vol. 4, No. 4, pp. 103-108, 3 text-figs.

(1907): The morphology of Coeloplana. Zool. Jahrb., Abt. Anat. Ontog., Vol. 24, No. 1, pp. 41-70, Pls. 8-10, Text-figs. A-D.

DAwYdoff, G.N. (1938): Les coeloplanides indochinoises. Arch. Zool. Exp. Gén., Vol. 80, pp. 125-162, $1 \mathrm{pl}$.

Komar, T. (1920): Notes on Coeloplana bockin. sp. and its development. Annot. Zool. Japon., Vol. 9, No. 5, pp. 575-584, 5 text-figs.

(1922): Studies on two aberrant ctenophores, Coeloplana and Gastrodes. Kyoto, 102 pp., 9 pls., 3 text-figs.

(1942): Lyrocteis and its allies. Part 3. Plants and Animals, Vol. 10, No.3, pp. 209-216, Text-figs. 10-17. (in Japanese)

KRUMBaGH, Th. (1933): Ueber eine kriechende Ctenophore aus dem Golfe von Suez und ein paar Thesen über eine Architektonik der Rippenquallen. Mitt. Zool. Mus. Berlin, Vol. 19, pp. 475-479, 1 text-fig.

Matthews, D. C. and S. J. Townsley (1964): Additional records of Hawaiian Platyctenea (Ctenophora). Pacific Sci., Vol. 18, No. 3, pp. 349-351.

Mortensen, Th. (1927): Papers from Dr. Th. Mor'ensen's Pacific Expedition 1914-16. 39. Two new ctenophores. Vidensk. Medd. fra Dansk naturh. Foren., Vol. 83, pp. 277-288, Pl. 3, 4 text-figs.

TANaKa, H. (1931): Reorganization in regenerating pieces of Coeloplana. Mem. Coll. Sci. Kyoto Imp. Univ. Ser. B, Vol. 7, No. 5, pp. 223-246, Pl. 18, 16 text-figs.

(1932): Coeloplana echinicola n. sp. Mem. Coll. Sci. Kyoto Imp. Univ. Ser. B, Vol. 7, No. 5, pp. 247-250, P1. 19.

Threl, H. (1968): Coeloplana meteoris nov. spec. (Ctenophora, Platyctenea), Beschreibung und systematische Stellung mit einem Vergleich der Gastrovascularsysteme in dieser Ordnung. Meteor Forsch.-Ergebn., D-Hft. 3, pp. 1-13, 18 text-figs.

Utinom, H. (1963): Coeloplana komaii, a new creeping ctenophore from Sagami Bay.Jap.Jour. Zool., Vol. 14, No. 1, pp. 15-19, 5 text-figs.

P.S. Just recently, it was reported that two living specimens of Coeloplana willeyi were found on a cyclostomatous polyzoan colony, Entalophora purpurascens (HutToN), stranded on the shore at Pakiri, Northland, New Zealand. The smaller individual was $13 \mathrm{~mm}$ long, strong orange in colour, and was provided with 16 dorsal tentacles (=aboral papillae). The larger one was $23 \mathrm{~mm}$ long, dark red in colour, with 33 dorsal tentacles, and was noted by the irregular, asymmetrical position of the statocyst. Gordon, D. P. (1969): A platyctenean ctenophore from New Zealand. N. Z. Jour. Mar. Fresh. Res., Vol. 3, No. 3, pp. 466-471, 2 text-figs. 